\title{
Conspicuous decline of Fucus in Kiel Bay (Western Baltic): what are the causes?*
}

\author{
Helge Vogt, Winfrid Schramm
}

Institut für Meereskunde, Universität Kiel, Düsternbrooker Weg 20, D-2300 Kiel 1, Germany

\begin{abstract}
In the framework of investigations on possible effects of eutrophication on the macrophytobenthos in Kiel Bay (Western Baltic), a large-scale survey of the distribution and occurrence of the genus Fucus was carried out in 1987/88. For large-scale quantitative mapping, underwater television was employed or direct observations from the water surface were made. Species composition and quantitative biomass data were obtained by dredging and SCUBA-diving. Comparison with the results of earlier investigations revealed a drastic decline in Fucus biomass from between 40000 and $45000 \mathrm{t}$ wet wt down to only $2400 \mathrm{t}$ wet wt in $1987 / 88$, which means a decrease by 94 to $95 \%$. Whereas Fucus vesiculosus as well as $F$. serratus were still frequent at depths below $2 \mathrm{~m}$ down to $13 \mathrm{~m}$ in the seventies, during our investigation Fucus spp. was not found in water depths greater than $2 \mathrm{~m}$. Possible causes for the observed changes are discussed, and it is concluded that decreased light levels or increased epiphyte growth as a result of eutrophication, and the reduction of substrate for algal growth due to stone fishing and sand deposition, are the main causes for the decline of Fucus spp.
\end{abstract}

\section{INTRODUCTION}

The bladder wrack Fucus vesiculosus $\mathrm{L}$. is the most conspicuous community-forming macrophyte on hard substrates of the upper littoral in the Baltic Sea.

From the late seventies on, an extensive decline in Fucus communities has been observed in different parts of the Baltic, especially on the Finnish coasts (Luther 1981, Kangas et al. 1982, Haathela 1984, Hällfors et al. 1984, Rönnberg et al. 1985, Kautsky et al. 1986, von Wachenfeldt et al. 1986, Wennberg 1987 , Rönnberg \& Haathela 1988).

Among the various causes which have been discussed, increasing eutrophication of the coastal areas has been considered as one of the primary causes for the decline. Increasing nutrient levels may result in increased phytoplankton production, i.e. higher turbidity and decreasing light transmission, but also in the massive development of annual filamentous algae, particularly of Fucus epiphytes, which in turn may be the reason for an invasion by Idotea or Mytilus.

Other potential reasons which have been considered

- This study was carried out within the framework of the project 'Eutrophication of the North Sea and the Baltic' of the Umweltbundesamt (Federal environmental Agency, Germany) under contract no. 10204215/17 are ice-scouring and -lifting, diseases, or pollutants such as heavy metals, pesticides and detergents (Kangas et al. 1982, Rönnberg \& Haathela 1988).

The only previous survey of Fucus beds in Kiel Bay (Western Baltic) was made in 1950/51 (Hoffmann 1952). It showed that at this time $F$. vesiculosus and $F$. serratus were the dominant macrophytic components down to $6 \mathrm{~m}$ depth. On the basis of Hoffmann's data and estimates of Fucus spp. occurrence below $6 \mathrm{~m}$ depth - as obtained by underwater TV observations and dredging - Schwenke (1965) calculated a total Fucus spp. standing crop of 35000 to 40000 t wet wt.

Only in 1987/88, after $35 \mathrm{yr}$, was a revised study of the macrophytes of the shallow as well as deeper areas of Kiel Bay feasible again (Breuer \& Schramm 1988, Schramm 1988).

This study, as part of the shallow water investigations, is concerned with the quantitative distribution of the genus Fucus in the German part of Kiel Bay. Changes in the occurrence of Fucus spp. in comparison to Hoffmann's (1952) and to Schwenke's (1965) surveys, as well as possible reasons, will be discussed.

\section{MATERIAL AND METHODS}

For the survey in 1950/51, Hoffmann (1952) used a simple underwater viewer. At that time, visibility 
extended down to $6 \mathrm{~m}$ depth, so that estimates of the density of the Fucus spp. beds were possible by direct observation from on board a small motor boat zigzagging from the shore to the $6 \mathrm{~m}$ depth line. The observed densities within the Fucus beds (expressed as coverage classes 0 to 4 ) were related to quantitative biomass samples taken at random by divers.

During our investigations in $1987 / 88$, the visibility was usually reduced to 2 to $3 \mathrm{~m}$ depth. For this reason the shallow water area from 0 to $6 \mathrm{~m}$ depth (total area $=$ $128 \mathrm{~km}^{2}$ ) had to be divided into the following 3 zones, each requiring individual methods:

0 to $1 \mathrm{~m}$ depth: The extension of the Fucus sp. belt close to the water's edge was calculated by pacing its length and width. Areas with different species composition or coverage were recorded as separate units.

1 to $2 \mathrm{~m}$ depth: This zone was surveyed using an inflatable boat equipped with an underwater viewer.

2 to $6 \mathrm{~m}$ depth: For depths greater than $2 \mathrm{~m}$, an underwater television camera (Osprey Electr., Scotland) was employed from on board a small research vessel. Depending on the extension of this depth range, the boat cruised either in the wider parts on zig-zag courses between the 2 and $6 \mathrm{~m}$ isolines, or in the narrower parts on courses parallel to the coast. The television observations (type of substrate, vegetation and coverage) were recorded every $30 \mathrm{~s}$. The position (Decca navigation) was printed every $150 \mathrm{~s}$. In addition to these investigations, a series of diving-, televisionand dredging profiles down to $10 \mathrm{~m}$ depth were carried out to detect the present lower boundaries of distribution of Fucus spp.

Five classes of coverage were used to quantify the recorded observations. The corresponding biomass values were obtained as means of five $1 \mathrm{~m}^{2}$ samples each collected at random by divers from various locations (Table 1).

Table 1. Classes of coverage and biomass (number of samples, arithmetic mean, standard deviation)

\begin{tabular}{|cccc|}
\hline $\begin{array}{c}\text { Coverage } \\
\text { class }\end{array}$ & \multicolumn{4}{c|}{ Biomass $\left(\mathrm{g}^{\mathrm{n}}\right.$ wet wt $\left.\mathrm{m}^{-2}\right)$} \\
& $\mathrm{n}$ & $\overline{\mathrm{x}}$ & $\mathrm{s}$ \\
\hline 0 & - & 0 & - \\
1 & 5 & 950 & 167 \\
2 & 5 & 2430 & 150 \\
3 & 5 & 3010 & 299 \\
4 & 5 & 4020 & 309 \\
\hline
\end{tabular}

Unfortunately, the data given by Hoffmann (1952) do not allow statistical treatment. He himself, however, assumes a relative error of $\pm 25 \%$ for his estimates.

We have considered the standard errors in biomass determination, patchiness and errors in determination of the dimension of the Fucus spp. beds, and we estimate the total relative error of our biomass computation to be $\pm 50 \%$.

\section{RESULTS}

One of the most striking results was that no attached Fucus spp., not even one individual plant, could be observed in water depths greater than $2 \mathrm{~m}$. In the late seventies, attached Fucus spp. was still frequently found at water depths down to $10 \mathrm{~m}$, as documented by Black (1978).

In the zone between 0 and $2 \mathrm{~m}$ depth Fucus vesiculosus is still an important component of the marine vegetation, whereas $F$. serratus was rare and occurred mainly at 1 to $1.5 \mathrm{~m}$ depth.

In most cases, Fucus spp. grow in belts of 5 to $20 \mathrm{~m}$ width. An exception was in the Bay of Orth (Island of Fehmarn) where sparsely distributed $F$. vesiculosus covered extended areas.

The coverage of Fucus spp. is widely dependent on suitable substrate. Highest densities (Coverage 3 and 4) were usually found at the foot of cliffs.

The total area covered by Fucus spp. was calculated as $29 \mathrm{~km}^{2}$, which is just $2 \%$ of the shallow water area between 0 and $6 \mathrm{~m}$ depth. The mean biomass was $71 \mathrm{~g}$ wet wt $\mathrm{m}^{-2}$. The total Fucus spp. biomass along the German coast of Kiel Bay was calculated at $2417 \mathrm{t}$ wet wt.

\section{DISCUSSION}

Comparison of the results of Hoffmann (1952) and Schwenke (1965) with our findings reveals a drastic decline in Fucus spp. in Kiel Bay. In 1950/51, during Hoffmann's investigations, 2 Fucus species were the dominant seaweeds down to $6 \mathrm{~m}$ water depth. For the German part of Kiel Bay (Falshöft to the NW tip of Fehmarn), the total Fucus spp. biomass was calculated at about $26000 \mathrm{t}$ wet wt. Schwenke (1965) estimated that Fucus spp. from areas below $6 \mathrm{~m}$ depth would add another 10000 to $15000 \mathrm{t}$ wet wt. A military restricted area in Howacht Bight, which could not be investigated by Hoffmann, covers about $13 \%$ of the total Fucus spp. area. In this area, rich in glacial hard substrates suitable for algal growth, the average coverage class is 3 . Therefore probably 4000 to $5000 \mathrm{t}$ must be added to the total of 36000 to $41000 \mathrm{t}$ wet wt. A total biomass of only 2417 t wet wt in $1987 / 88$, as calculated by us, means a reduction by more than $90 \%$ in the total area investigated.

Regional differences were observed (Fig. 1). The most dramatic decline occurred in Area V where only $0.14 \%$ of the biomass determined by Hoffmann remained. The elimination of Fucus spp. at depths of 
Fig. 1. Fucus spp. biomass (t wet wt) and distribution in different coastal areas of Kiel Bay as determined by Hoffmann between 1950 and 1952 (hatched bars and areas) and in this study between 1987 and 1988 (solid bars and areas)

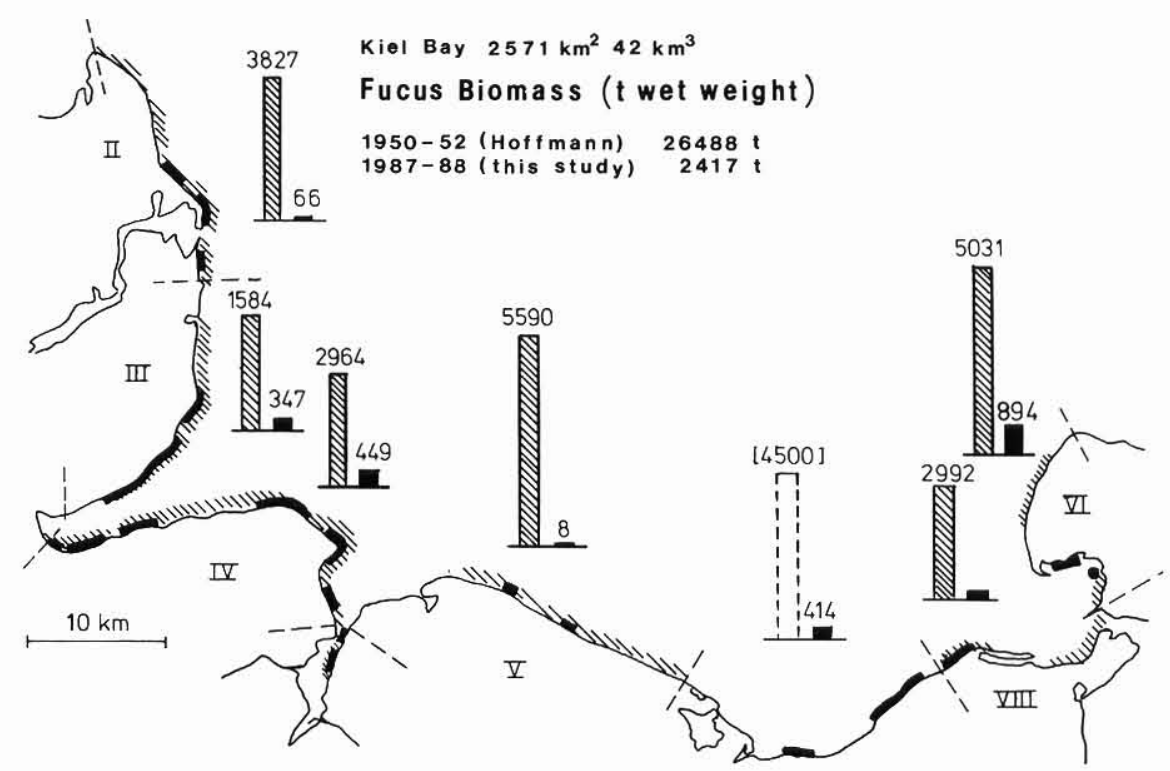

more than $2 \mathrm{~m}$ probably happened during the last $10 \mathrm{yr}$, since Black (1978) still found and documented Fucus spp. down to $10 \mathrm{~m}$ depth at the end of the seventies.

To explain the drastic decline in Fucus spp. in the Baltic, various causes or their combination have been suggested and discussed, as mentioned earlier. A model including the major potential causes is proposed in Fig. 2. Among these probably the most important factors are indicated by heavier lines. Of minor importance may be infectious diseases caused by, for example, fungi, bacteria, parasitic algae or nematodes, although hardly any information is available. Since, to our knowledge, no visible symptoms, such as abnormal growth, galls, etc. have been observed during the past

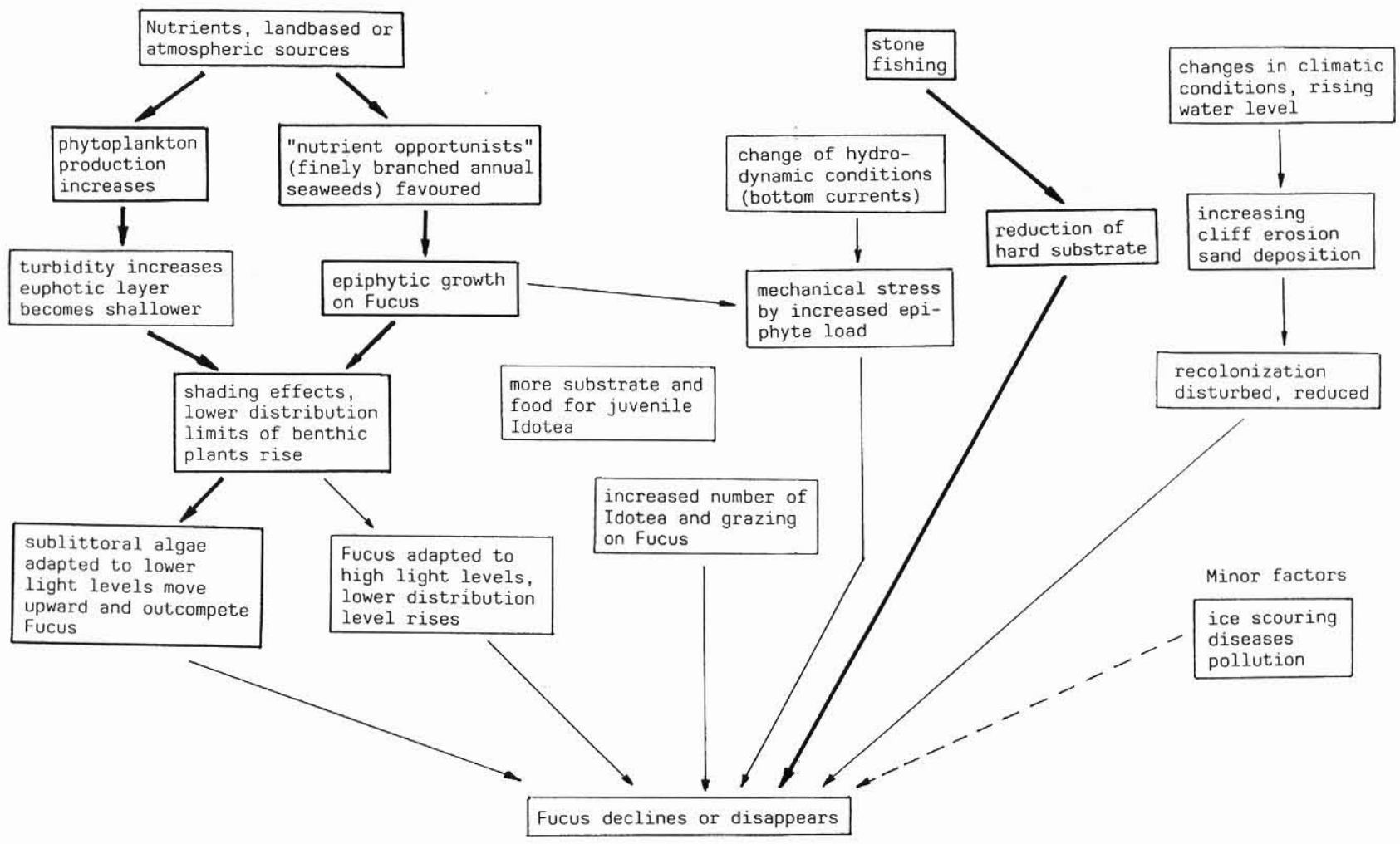

Fig. 2. Hypothetic model including major causes for the Fucus spp. decline in Kiel Bay 
few years, we may exclude infectious diseases, at least in epidemic dimensions. Similarly, the effects of crude oil or its derivatives which may have detrimental effects on Fucus spp. populations (Thomas 1973, cited in Andrews 1976) may be excluded, as no serious oil spillage occurred in Kiel Bay during the past few decades. It is also unlikely that levels of pollutants as far as known for Baltic coastal waters, such as heavy metals, radioactive substances or pesticides, have affected the vitality of Fucus spp.

Ice scouring or abrasion, which occurred several times during hard winters in the past decade, would have extinguished nearshore communities between 0 and $2 \mathrm{~m}$ depth, and, to a lesser extent, the deeper growing Fucus spp. However, these disappeared almost completely. What is more, future ice scouring may endanger the remaining Fucus spp. populations, especially because recruitment by spores from the ice safe' deeper growing population is no longer possible. The uplifting of Fucus spp. plants by so-called 'anchor ice', as reported by Rönnberg \& Haathela (1988) in the Finnish archipelago, has not been observed along the more exposed coasts of Kiel Bay.

Among the more important factors which may be responsible for the decline in Fucus spp., and which is typical for the Kiel Bay, is the loss of substrates suitable for Fucus spp. settlement through deposition of eroded cliff material. Along the coasts of Kiel Bay (including Flensburg Fjord), of the approximately $90 \mathrm{~km}$ of cliffs, nearly $35 \mathrm{~km}$ are 'active', i.e. they are subject to erosion through wave action (Klug et al. 1988). From these cliffs about $75000 \mathrm{~m}^{3} \mathrm{yr}^{-1}$ are washed into Kiel Bay. About 35 to $40 \%$ of this material, in particular coarser sand, gravel and stones, is deposited near the shore line, depending on water motion and currents, whereas finer materials are transported to deeper areas. During the past few years we have observed, at the foot of some cliffs, the formation and extension of sandy floors and sandbanks which in some places have significantly reduced the hard substrate (boulders and pebbles). Theoretically, the nearshore deposition of some 30 to $40 \%$ of the eroded material (roughly 2 to $3 \times 10^{5} \mathrm{~m}^{3}$ $\mathrm{yr}^{-1}$ ) in a $10 \mathrm{~cm}$ thick layer would just cover 2 to $3 \mathrm{~km}^{2}$ of the $128 \mathrm{~km}^{2}$ between 0 and $6 \mathrm{~m}$ depth. This shows that the drastic decline in Fucus spp. can hardly be attributed to erosion and sand cover, although these processes may be effective in certain limited areas.

Until the early seventies, stone fishing, i.e. the commercial gathering of glacial rock material for construction purposes, was common in Kiel Bay, as in most German and Danish coastal waters. The peak of stone fishing was reached during World War II, when helmet divers were employed to extend the search for stones down to 8 to $10 \mathrm{~m}$ water depth. Breuer \& Schramm (1988) estimate that, all in all, $1.5 \times 10^{6} \mathrm{t}$ of stones (or
$5.6 \times 10^{6}$ medium size stones of $\sim 0.5 \mathrm{~m}$ diam.) were landed within $40 \mathrm{yr}$. Assuming an average stone size of $0.5 \mathrm{~m}$ diam. and a more or less spherical shape, and provided that half of the stone surface is available as a substrate for seaweed growth, we calculate that ca 2.8 $\mathrm{km}^{2}$ potential hard substrate surface for Fucus spp. growth has been removed. Assuming further that this substrate is covered with Fucus spp. at a mean density of 2.5 to $3 \mathrm{~kg}$ wet wt m $\mathrm{m}^{-2}$ (coverage classes 2 and 3 ), the total loss due to reduction of hard substrate would not exceed 7000 to $8400 \mathrm{t}$. As stone fishing attained a maximum in the forties and ended in the seventies, for the observed disappearance of Fucus spp. at depths greater than $2 \mathrm{~m}$, other causes must be responsible. However, it cannot be excluded that the reduction in potential habitats may have impaired the competitive vitality of the Fucus spp. populations, e.g. through lower spore production, and thus reduced potential for recruitment.

Eutrophication as one of the principal causes of the changes in macroalgal vegetation in coastal waters of the Baltic has been discussed (Kangas et al. 1982, Kautsky et al. 1986, Wennberg 1987). Increasing nutrient levels have been observed in various parts of the Baltic. In the inner part of Kiel Bay, only in the mixed winter water was an increase in total phosphorus from 1 to $1.5 \mu \mathrm{mol} \mathrm{dm}{ }^{-3}$ found for the period 1971 to 1984 . No changes in nitrogen concentration were observed, although the additional input of nutrients, particularly of nitrogen, into Kiel Bay as a result of human activity are considerable (Babenerd \& Zeitzschel 1985, Gerlach 1986).

Despite the fact that the pathways of nutrient imports and exports are not yet known, there are some indications that primary producers respond to the additional nutrient supply. From chlorophyll $a$ as well as from protein determinations (Lohmann 1908, Smetacek 1975), it may be deduced that the plankton biomass nearly doubled from 1958 to 1975 (Babenerd \& Zeitzschel 1985, Babenerd 1986).

A direct response of the nearshore algal vegetation to increased nutrient supply may be seen in the spread of finely branched forms, particularly of the Fucus spp. epiphytes Pilayella litoralis and Ectocarpus confervoides, and of some folious green and red algae in Kiel Bay, as also described for some Finnish or Swedish coasts (Kangas et al. 1982, Wennberg 1987). Most of these 'opportunistic' annual forms are characterized by high nutrient uptake rates and nutrient saturation levels as well as by fast growth, which may be of competitive advantage over the comparatively less active Fucus spp. plants (Wallentinus 1984).

Competition for nutrients seems to be of lesser importance, since nutrient levels in the algal beds are usually considerably higher than in the water column 
and sufficient for saturated growth of Fucus spp. throughout the year (Schramm et al. 1988). More probably the impairment of the light climate through overgrowing and shading by the epiphytes may contribute to the decline of Fucus spp.

Unfortunately, there are no long-term light or transmission measurements for the nearshore waters of Kiel Bay available for the last decade. However, there are some indications that, as a result of increasing plankton density, the turbidity of the water in Kiel Bay has increased. As already mentioned, Hoffmann (1952) was able to carry out his survey with a simple underwater viewer from the water surface down to 6 to $8 \mathrm{~m}$ depth, while during our investigations visibility was usually reduced to between 2 and $3 \mathrm{~m}$ depth. Similar observations have been reported for the Baltic proper, where the Secchi depths decreased by 1 to $2 \mathrm{~m}$ from the fifties to the end of the seventies (Kautsky et al. 1986). Especially in the sublittoral (deeper than $2 \mathrm{~m}$ ), light may become limiting to the 'strong light form' Fucus spp., in competition with low-light adapted algae, such as Phycodrys rubens, Polysiphonia nigrescens or Phyllophora truncata which have widely replaced Fucus spp. communities beyond $2 \mathrm{~m}$ depth.

Another indication of changes in the light climate may be that in summer 1989 in the upper littoral of the Kiel Fjord we observed an unusual outburst of Laminaria saccharina (Schramm \& Reusch unpubl.), a seaweed which up to now has been considered as a typical low-light adapted deep-water form in the Western Baltic. From $0.5 \mathrm{~m}$ down to $6 \mathrm{~m}$ depth the dense L. saccharina populations have practically completely replaced Fucus spp.

Apart from competition between plants, the possible detrimental effects of some animals must be considered. During the past few years, an increase in Mytilus edulis has been observed, possibly as a result of increasing planktonic food supply. During the mass development of blue mussels, larvae may also settle on Fucus spp., particularly when overgrown with epiphytes (Kangas et al. 1982). The detrimental effects of unusually dense $M$. edulis settlements on Halidrys siliquosa were reported by Lundälv et al. (1986), although we did not observe this phenomenon during our investigations.

Filamentous algae may serve as food for juvenile Idotea spp., whereas adults may also graze on Fucus spp., and daily consume one half of their body weight (Jansson 1974). Also in Kiel Bay, I. baltica is abundant. In Fucus spp. culture experiments in situ, Idotea sp. reduced the biomass by $30 \%$ within nearly 2 mo (Grützmacher 1983). During the period of this study, neither mass occurrence of Idotea sp. on Fucus spp. nor characteristic grazing marks were found.

In conclusion, we may say that of the various possible causes of the documented decline in Fucus spp., changes in the light climate, as a secondary effect of eutrophication, are most likely the prime factor. We may distinguish between direct effects on the growth of Fucus spp. by shading through the mass development of epiphytes or, at depths of over 2 to $3 \mathrm{~m}$, the reduction of the available light to suboptimal levels through increased turbidity. Indirect effects of decreased light levels may be the competitive advantage of low-light adapted algae, which are able to intrude into the former habitats of Fucus spp. On the other hand, sand deposition and the reduction of suitable substrates for Fucus spp. as a result of stone fishing, or through the massive development of Mytilus edulis, may play a certain role in Kiel Bay.

Acknowledgements. We would like to thank T. Henningsen, H. Jähmlich and M. Waltemath for their technical assistance, and Cpt. H. Manthe of the research vessel 'Sagitta' for his great support during the survey. We gratefully acknowledge the correction of the English manuscript by Dr Brunt.

\section{LITERATURE CITED}

Andrews, J. H. (1976). The pathology of marine algae. Biol. Rev. 51: 211-253

Babenerd, B. (1986). Long-term observations of some hydrographical, chemical, and planktological variables in Kiel Bay, 1957-1975. ICES C.M. 1986/L:19 biol. Oceanogr. Committee, p. 1-8

Babenerd, B., Zeitzschel, B. (1985). Trends für eintragsrelevante Faktoren und für die Nährsalzkonzentrationen im Wasser der Kieler Bucht. Ber. Inst. MeeresKde 148: $1-45$

Black, H. (1978). Vegetationsdynamische Untersuchungen an epilithischen Algengemeinschaften im Sublitoral der Westlichen Ostsee unter Berücksichtigung der produktionsbiologischen Bestandsabschätzung. Rep. SonderforschBereich 95 (Univ. Kiel) 44: 1-144

Breuer, G., Schramm, W. (1988). Changes in the macroalgal vegetation of Kiel Bight (Western Baltic Sea) during the past 20 years. Kieler Meeresforsch. (Sonderh.) 6: 241-255

Gerlach, S. (1986). Langfristige Trends bei den Nährstoffkonzentrationen im Winterwasser und Daten für eine Bilanzierung der Nährstoffe in der Kieler Bucht. Kieler Meeresforsch. 31: 153-174

Grützmacher, M. (1983). Produktionsökologische Untersuchungen an Fucus-Beständen der Kieler Bucht (Westliche Ostsee). Diss. Universität Kiel, p. 1-108

Haathela, I. (1984). A hypothesis of the decline of the bladder wrack (Fucus vesiculosus L.) in SW Finland in 1975-1981. Limnologica, Berlin 15: 345-350

Hällfors, G., Kangas, P., Niemi, A. (1984). Recent changes in the phytal at the south coast of Finland. Ophelia (Suppl.) 3: $51-59$

Hoffmann, C. (1952). Über das Vorkommen und die Menge industriell verwertbarer Algen an der Ostküste SchleswigHolsteins. Kieler Meeresforsch. 9: 5-14

Kangas, P., Autio, H., Hällfors, G., Luther, H., Niemi, A. Salemaa, H. (1982). A general model of the decline of Fucus vesiculosus at Tvärminne, south coast of Finland in 1977-1981. Acta Bot. fenn. 118: 1-27 
Kautsky, N., Kautsky, H., Kautsky, U., Waern, M. (1986). Decreased depth penetration of Fucus vesiculosus since the 1940's indicates eutrophication of the Baltic Sea. Mar. Ecol. Prog. Ser. 28: 1-8

Klug, H., Sterr, H., Boedeker, D. (1988). Die Ostseeküste zwischen Kiel und Flensburg. Geogr. Rdsch. 5: 6-14

Lohmann, H. (1908). Untersuchung zur Feststellung des vollständigen Gehaltes des Meeres an Plankton. Wiss. Meeresunters. N.F. 10: 131-370

Lundälv, T., Larsson, C. S., Axelsson, L. (1986). Long-term trends in algal-dominated subtidal communities on the Swedish west coast - a transitional system? Hydrobiologia 142: 81-95

Luther, H. (1981). Occurrence and ecological requirements of Fucus vesiculosus in semi-enclosed inlets of the Archipelago Sea, SW Finland. Ann. Bot. fenn. 18: 187-200

Rönnberg, O., Haathela, I. (1988). Does anchor ice contribute to the decline of Fucus in the Baltic? Mar. Pollut. Bull. 19: 388-389

Rönnberg, O., Letho, J., Haathela, I. (1985). Recent changes in the occurrence of Fucus vesiculosus in the Archipelago Sea, SW Finland. Ann. Bot. fenn. 22: 231-244

Schramm, W. (1988). Untersuchungen zur Rolle benthischer

This article was submitted to the editor
Primärproduzenten im organischen und anorganischen Stoffhaushalt der Kieler Bucht. Ber. 10204215/17: Eutrophierung der Nord- und Ostsee. Umweltbundesamt, Berlin, p. 1-34

Schramm, W., Abele, D., Breuer, G. (1988). Nitrogen and phosphorus nutrition and productivity of two community forming seaweeds (Fucus vesiculosus, Phycodrys rubens) from the Western Baltic (Kiel Bight) in the light of eutrophication processes. Kieler Meeresforsch. (Sonderh.) 6: 221-240

Schwenke, H. (1965). Beiträge zur angewandten marinen Vegetationskunde der westlichen Ostsee (Kieler Bucht). Kieler Meeresforsch. 21: 144-152

von Wachenfeldt, T., Waldemarsson, S., Kangas, P. (1986). Changes in the littoral communities along the Baltic coasts. Baltic Sea Envir. Proc. 19: 394-403

Wallentinus, I. (1984). Comparison of nutrient uptake rates for Baltic macroalgae with different thallus morphologies. Mar. Biol. 80: 215-255

Wennberg, T. (1987). Long-term changes in the composition and distribution of the macroalgal vegetation in the southern part of Laholm Bay, south-west Sweden, during the last thirty years. Naturvårdsverket Rapport 3290: 1-47 (in Swedish)

Manuscript first received: January 23, 1990

Revised version accepted: August 22, 1990 